\title{
KORELASI IDENTIFIKASI APATISME POLITIK DENGAN KEBIJAKAN PUBLIK KOTA MEDAN
}

\author{
Dwi Ardiyanti, Ibnu Zulian \\ Program Studi Hubungan Internasional \\ Fakultas Ilmu Sosial dan Politik, Universitas Potensi Utama \\ ardiyanti.1987@gmail.com, ibnuzulian45@gmail.com
}

\begin{abstract}
ABSTRAK
Pemilihan Kepala Daerah (Pilkada) Provinsi Sumatera Utara menjadi sorotan penting di Indonesia, yaitu bagaimana sebuah apatisme politik masyarakat berkorelasi dengan efektifitas kebijakan publik. Kota Medan yang merupakan ibukota provinsi Sumatera Utara merupakan salah satu kota dengan tingginya golput (golongan putih) dalam partisipasi poltitik, kajian ini sangat menarik karena membahas apatisme masyarakat dalam pemilihan kepada daerah Sumatera Utara dan kaitannya dengan efektifitas kebijakan publik. Kasus korupsi telah menjadi fakta dalam kepemipinan kepala daerah di propinsi Sumatera Utara. Bagi sebagian besar masyarakat, apatisme terhadap partisipasi politik merupakan hal yang biasa. Dalam penelitian ini dibahas tentang beberapa faktor yang menyebabkan sikap apatis itu terjadi, diantaranya politik identitas, minimnya sosialisasi atas parpol, kekerasan struktural, hingga penurunan kepercayaan publik terhadap proses politik itu sendiri. Penelitian ini menyajikan data dan teori sebagai konsep yang digunakan dalam melihat secara objektif fenomena apatisme terhadap partisipasi politik yang terjadi di kota Medan, Sumatera Utara. Dalam penelitian ini akan dibahas dan dianalisa penyebab tingginya angka Golongan Putih (Golput) yang disebabkan oleh sikap apatis masyarakat Kota Medan dalam pemilihan Gubernur Sumatera Utara. Penelitian kualitatif ini menggunakan data yang diperoleh dari berbagai sumber, diantaranya, hasil wawancara, buku, artikel koran, berita, website, jurnal, dan beberapa sumber resmi lainnya. Akhirnya, penelitian ini bertujuan untuk menganalisa bagaimana tingginya angka golput akibat sikap apatis berpengaruh terhadap kebijakan publik di kota Medan, Sumatera Utara.
\end{abstract}

Kata kunci: pemilihan kepala daerah, apatisme, korelasi, partisipasi politik, kebijakan publik

\section{ABSTRACT}

Governenor election of North Sumatera is being highlithted in Indonesia, in terms of how political apatism of citiznes may correlate with effectivity of public policy. Medan is the capital city of North Sumatera, which occupy as one of the highest city with abstention of political participation, this study is very interesting since it discusses about citizens apatism for governor political participation in North Sumatera and correlate it with effectivity of public policy. Corruption cases becomes the real fact in the local leadership in North Sumatera province. For most of the citizens, apatism in political participation is an common thing to do. In this study will be discussed few factors of political apatism, 
such as political identity, the less of political socialiation by political party, structural violence on politic, and the lowering public trust on political process itself. This study provided data and theory as concept which can be used to see apatism in Medan, North Sumatera, as a phenomenon objectively. In the study will be discussed and analyzed the reason of higher number of aabstention on political participation which may be caused by Medan citizens' apatism on governor election of North Sumatera. This qualitative research used obtained data from sources, such as books, newspaper articles, news, website, journals, and other official sources. Finally, this study is aimed to analyze how the high abstention caused by apatism correlate with public policy in Medan, North Sumatera.

Keywords : governor election, apatism, correlation, political participation, public policy

\section{PENDAHULUAN}

\section{Latar Belakang}

Penurunan angka partisipan (pemilih) dalam pemilihan kepala daerah (Pilkada) di Sumatera Utara dari tahun ke tahun memperlihatkan sisi lain dari pola interaksi masyarakat majemuk. Masyarakat yang tinggal di propinsi Sumatera Utara, khususnya di Medan merupakan masyarakat yang majemuk karena terdiri dari berbagai suku bangsa, ras, maupun agama kemudian bersosialiasi dan berafiliasi sebagai makhluk sosial. Masyarakat di wilayah Medan merupakan pola afiliasi yang menarik antara suku (etnis) maupun agama. Sebagian besar masyarakat Medan merupakan suku atau etnis Melayu, Jawa, Batak, Mandailing, Karo, Aceh, Sunda, Tionghoa, dan beberapa suku yang lain. Masyarakat tersebut kemudian terbagi menjadi beberapa komunitas agama yaitu Kristen Protestan (sebagian besar Batak), Islam (Melayu, Mandailing), Hindu (India), Budha (Tionghoa) (diambil dari ceritamedan.com dan wikipedia). Pola interaksi masyarakat yang majemuk menjadi salah satu kajian yang menarik dari segi politik dalam Ilmu Hubungan Internasional mengingat adanya polarisasi dukungan politik sesuai suku (etnis) dan agama di kota Medan. Hal ini kemudian diakaitkan dengan dengan menurunnya tingkat partisipan (pemilih) pemilihan daerah, terutama dalam pemilihan kepala daerah (Pilkada) Sumatera Utara.

Tingkat kepercayaan publik kepada aktifitas politik maupun para pemangku jabatan yang berwenang di wilayah Sumatera Utara menurun. Kurangnya sosilisasi dan partisipasi politik bagi sebagian besar masyarakat Sumatera Utara diidentifikasi sebagai masalah yang utama. Namun, asumsi ini belum terbukti hingga ada keterangan dari perwakilan KPU. Keluhan tentang keterbatasan masyarakat untuk mengakses informasi tentang latar belakang, tujuan, visi misi, maupun kebijakan yang akan dibuat oleh kandidat terpilih 
menyebabkan gagalnya proes sosialisasi politik hingga berujung pada tingginya angka apatisme dalam partisipasi politik masyarakat.

Sosialisasi politik merupakan salah satu media yang penting untuk menumbuhkembangkan iklim demokrasi. Pemilihan kepala daerah merupakan salah satu implementasi demokrasi yang sudah dimulai pasca kelengseran rezim orde baru. Namun, meningkatnya iklim di demokrasi melalui pemilihan langsung berbanding terbalik dengan kenyataan bahwa partisipasi politik masyarakat mengalami penurunan yang signifikan. Sebagian besar sosialisasi tentang politik dilakukan ketika akan diadakan pemilihan, dalam hal ini pemilihan kepala daerah. Kenyataan bahwa dua kali Gubernur Sumatera Utara tertangkap dan terbukti melakukan korupsi ketika menjabat sebagai kepala daerah, diidentifikasi menjadi salah satu faktor utama penyebab menurunnya partisipasi politik dalam pemilihan kepala daerah.

Oleh karena itu, penelitian ini akan menganalisa sejauh mana tingkat apatisme dalam partisipasi politik masyarakat dan korelasinya dengan kebijakan publik. Penelitian akan berfokus pada pemilihan kepala daerah tahun 2013 untuk pemilihan Gubernur Sumatera Utara.

\section{PEMBAHASAN}

\section{Politik Identitas}

Politik identitas seperti kesukuan yang ditampilkan oleh bakal calon terpilih dalam Pilkada dengan latar belakang kesukuannya, merupakan salah satu pertimbangan penting dalam perilaku politik. Indra Kesuma Nasution (2014) menegaskan bahwa di Medan, Sumatera Utara, identitas kesukuan berpengaruh terhadap partisipasi politik, terutama perilaku politik dalam Pilkada langsung 2010. Terkait pengaruh faktor kesukuan dalam Pilkada, Edward Aspinall (2011) menjelaskan bahwa identitas kesukuan dalam pertarungan politik Pilkada digunakan dalam tiga hal, yaitu dalam memobilisasi simbol kesukuan, menjadi pertimbangan pemilih, dan seleksi dan strategi kandidat pemimpin (Hemay dan Munandar, 2016).

Identitas dalam politik berpengaruh terhadap tingkat partisipasi politik, termasuk di dalamnya partisipasi dalam pemilihan umum. Definisi partisipasi politik dalam konteks ini adalah tindakan seorang warga negara biasa yang dilakukan secara sadar untuk memengaruhi keputusan-keputusan publik. Maka, identitas individu dapat dimunculkan secara sosial dengan bermacam-macam faktor melalui suku, keagamaan, gender, 
kewarganegaran dan lain sebagainya. Politik identitas merupakan sebuah konsep dan gerakan politik yang fokus perhatiannya pada perbedaan sebagai suatu kategori politik yang utama (Hemay dan Munandar, 2016).

Manuel Castells (2010), membedakan identitas individu dalam tiga kategori, yaitu legitimite identity, resitance identity dan project identity. Pertama, Identitas Legitimasi (Legitimate Identity). Identitas jenis ini merupakan proses mengenalkan institusi dominan dari sebuah masyarakat untuk memperluas dan merasionalisasi dominasi mereka terhadap pelaku sosial. Dalam kasus minimnya angka partisipasi politik masyarakat kota Medan, legitimate identity merupakan salah satu faktor calon dengan marga tertentu menegaskan dominasi nya untuk mendapat legitimate identity di masyarakat luas dan mendulang suara untuk pemilihan.

Hingga saat ini, faktor kemajemukan masyarakat di Sumatera Utara masih dijadikan sebagai salah satu sumber daya penting untuk kendaraan politik. Dengan adanya berbagai kultur sosial, susunan masyarakat di Sumatera Utara yang beragam, membuat masyarakat harus rela membuat ciri khas dalam membentuk identitas dirinya agar menarik dan mampu menjadi sarana untuk mendulang suara dalam pemilihan kepala daerah. Tidak terkecuali, proses pengumpulan massa ketika kampanye yang kemudian melibatkan tokohtokoh masyarakat dominan. Dalam hal ini, dominasi kelompok tertentu di wilayah Sumatera Utara masih menjadi sumber penting dalam legitimate identity bagi pasangan calon Gubernur Sumatera Utara. Meskipun, tidak menutup kemungkinan masuknya pengaruh lain, misalnya karakteristik personal, untuk memilih karakter calon Gubernur Sumatera Utara.

Proses sosialisasi hingga kaderisasi seharusnya melibatkan masyarakat umum. Dalam hal ini, pihak partai memiliki wewenang serta tugas untuk mensosialisasikan kader partai, semantara Komisi Pemilihan Umum (KPU) kemudian melalui peraturan dan perundang-undangan akan mengawal proses kaderisasi hingga sosialisasi kader partai ke masyarakat agar tercipta suasana demokrasi yang damai, aman dan tertib. Tanpa kerjasama dari masyarakat, partai, maupun KPU mustahil iklim demokrasi dapat terwujud secara merata. Permasalahan di lapangan yang timbul, antara lain, adanya dominasi dari salah satu pihak masyarakat yang juga berpengaruh di partai untuk mempengaruhi masyarakat agar tidak terlibat secara aktif, yaitu dengan langsung membeli suara masyarakat tanpa melibatkan mereka dalam proses perumusan kebijakan. Berbeda dengan Jakarta sebagai ibukota yang juga kota metropolitan di Indonesia, proses pemilihan kepala daerah mampu dilaksanakan hingga dua kali putara terkait dengan perbedaan Anggaran Pendapatan 
Daerah DKI Jakarta dan Medan, Sumatera Utara. Pemilihan Gubernur di Sumatera Utara tidak mungkin berlangsung dua kali putaran. Oleh karena itu, kesempatan ini dimanfaatkan secara maksimal oleh pihak tertentu yang kemudian mendominasi suara dalam pemilihan kepala daerah dan menumbangkan lawan politiknya di tingkat daerah Sumatera Utara.

Legitimate identity tidak hanya diperlukan oleh individu sebagai pasangan calon, namun juga komunitas partai, suku, agama, dan ras yang majemuk di wilayah Sumatera Utara untuk mengenalkan institusi dominan dari sebuah masyarakat untuk memperluas dan merasionalisasi dominasi mereka terhadap pelaku sosial. Pelaku sosial yang dimaksud adalah mereka yang akan terlibat dalam proses pengambilan suara dalam pemilihan kepala daerah, dan masyarakat merupakan bagian terpenting dalam tahap ini.

Kedua, Identitas Perlawanan (Resistance Identity). Identitas ini merupakan sebuah identitas yang dipertahankan dengan melakukan perlawanan untuk mempertahankan identitas tersebut melalui stigma dari pihak yang mendominasi, Castells (2010). Identitas ini berfungsi membentuk proses perlawanan dan pertahanan atas perbedaan prinsip dalam institusi. Identitas perlawanan dapat dipahami secara sederhana sebagai sebuah identitas yang diperjuangkan dari awal hingga akhirnya mendapatkan pengakuan keabsahan atas identitas tersebut.

Identitas juga dapat digunakan sebagai media analisa terkait dengan penurunan angka partisipan dalam pemilihan kepala daerah Sumatera Utara. Setiap komunitas maupun individu yang bergelut untuk mendapatkan suara dalam pemilihan daerah harus berjuang untuk mempertahnakan dan melakukan perlawanan dari stigma yang mendominasi. Sebagai contoh, wilayah Sumatera Utara dengan dominasi uku dan agama tertentu memiliki stigma kuat, sehingga membuat warga yang berasal dari suku atau agama yang berbeda kemudian harus mencari sendiri sosok calon pemimpin yang akan dipercaya menjabat. Di sisi lain, masyarakat minoritas tidak dapat terlepas dari sulitnya akses politik yang memungkinkan mereka memegang jabara di wilayah Sumatera Utara. Akibatnya, tidak banyak calon pemimpin dari suku atau agama minoritas yang berkesempatan untuk menduduki jabatan Gubernur, tanpa adanya dukungan partai ataupun organisasi masyarakat yang mayoritas di wilayah Sumatera Utara.

Identitas perlawanan menjadi salah satu simbol kurangnya pemerintah daerah memfasilitasi masyarakat untuk menghilangkan stigma dominasi di kalangannya, sehingga membuat apatisme terhadapat partisipasi politik masyarakat minoritas cukup tinggi di wilayah Sumatera Utara. Hal ini juga dapat dijadikan sebuah pembelajaran bagi partai 
bahwa dalam kaderisasi partai, suara keterwakilan masyarakat minoritas dalam partai juga perlu diperhatikan.

Dalam konteks penurunan angka pemilih untuk wakil kepala daerah di Sumatera Utara, bakal calon yang berjuang untuk mendapatkan suara saling menegaskan identitas perlawanan yang berguna untuk mendapatkan simpati dari para calon pemilih, yaitu dengan cara melakukan pendekatan kepada masyarakat ketika kampanye. Pendekatan calon pasangan ini wajar dilakukan ketika kampanye, sesuai prosedur, namun perlakuan sebagai besar pasangan calon kepada masyarakat yang terkesan membela kepentingan rakyat kemudian dialami berbeda oleh masyarakat ketika calon sudah terpilih; hal ini yang membuat masyarakat juga menunjukkan identitas perlawanan terhadap keterlibatan mereka dalam partisipasi politik, pilkada misalnya.

Ketiga, Identitas Proyek (Project Identity) yaitu para pelaku sosial membangun sebuah identitas baru yang bertujuan mendefinisikan kembali posisi mereka dalam masyarakat dengan berusaha bertransformasi dari struktur sosial secara menyeluruh (Hemay dan Munandar, 2016). Identitas Proyek merupakan salah satu implementasi masyarakat yang merupakan calon pemilih untuk mengembalikan cara lama dalam budaya demokrasi. Tidak lagi melalui penegasan marga, agama, maupun komunitas tertentu, namun lebih kepada mengembalikan segala proses demokrasi pada nilai luhur dalam norma sosial. Namun, hal ini tidak mudah dilakukan karena masyarakat calon pemilih sudah lama mendapat stigma karakter atau penggambaran bakal calon yang terpilih nantinya tidak mampu membawa dampak yang positif bagi masyarakat. Hasilnya, stigma Korupsi, Kolusi, dan Nepotisme masyarakat terhadap para calon pemangku jabatan tetap melekat dan membuat masyarakat sebagai calon pemilih menjadi apatis dalam partisipasi politik.

Prakteknya, Identitas Proyek (Project Identity) merupakan salah satu cara ampuh bagi setiap pasangan calon yang akan maju dalam pemilihan kepala daerah . Masingmasing calon akan berlomba menciptakan citra diri yang baik dilihat oleh masyarakat sekitar, terutama ketika kampanye. Dengan meningkatnya pengetahuan dan akses informasi yang tidak dapat dibendung, masing-masing calon akan berupaya merangkul para tokoh masyarakat untuk membantu menciptakan proyeksi diri yang baik di mata masyarakat. Sehingga, Identitas Proyek (Project Identity) ini cara yang efektif untuk membuat masyarakat memasukkan surat suara untuk memilih.

Namun, pada kenyatannya sosialisasi dan kaderisasi partai di kota Medan bukan hal utama yang dilakukan oleh partai yang mengikuti pemilu. Akibatnya, penurunan angka 
pemilih dalam Pilkada tidak dapat dihindari dari tahun ke tahun. Hal ini kemudian mengarah dari apatisme terhadap partisipasi politik ke kekerasan struktural yang akhirnya melahirkan siklus penurunan angka kepercayaan publik yang terus memburuk dari tahun ke tahun. Meskipun para calon pemilih sudah mendapat informasi atau citra yang baik mengenai pasangan calon yang akan maju pemilihan kepala daerah, mereka tidak mendapat sosialisasi yang diharapkan. Proses untuk menggerakkan pemilih yang benarbenar ingin memberikan suaranya bukan hal mudah, hal ini adalah proses dari sosialisasi yang panjang dan melelahkan yang juga membutuhkan kerjasama dari berbagai pihak terkait, bukan hanya pihak yang berkepentingan di dalamnya. Kaderisasi dalam partai, misalnya, merupakan salah satu cara efektif membentuk citra diri yang baik, yaitu melalui keterlibatan secara aktif dalam kegiatan yang berfokus pada kepentingan masyarakat. Tidak akan ada suara rakyat tanpa aksi nyata positif yang melibatkan masyarakat sejak awal.

Fenomena iklim politik di Indonesia ini dapat dianalisa dengan pendekatan behavioral decision theory (BDT), Lau (2003) \& Redlawsk (2006). Pendekatan behavioral decision theory (BDT) mengasumsikan bahwa individu sebagai limited information processors. Pendekatan ini menganggap bahwa jumlah informasi yang dapat diolah oleh individu sangat terbatas. Keterbatasan individu dalam memproses jumlah informasi, biasa juga disebut bounded rationality (rasionalitas terikat). Menurut pendekatan ini, sebagai mahkluk rasional kognisi individu masih memiliki beberapa keterbatasan. Keterbatasanketerbatasan tersebut di antaranya adalah keterbatasan dalam menyimpan jumlah informasi, keterbatasan dalam mengolah informasi dan keterbatasan dalam memanggil kembali informasi yang telah diolah (Lau, 2003; Lau \& Redlawsk, 2006).

Dalam kasus apatisme pilkada Sumatera Utara, keterbatasan yang dimiliki oleh masyarakat sebagai pemilih, merupakan respon aktif yang diberikan karena kurangnya sosialisasi dan kaderiasasi partai yang melibatkan masyarakat dari awal, bukan hanya ketika kampanye. Keterbatasan tersebut juga dapat diidentikkan dengan turunnya angka pemilih dalam pemilihan kepala daerah Sumatera Utara. Masyarakat dengan keterbatasan informasi memiliki jurang yang besar untuk mengakses mereka yang justru meminta suara masyarakat.

Para bakal calon sibuk mempersiapkan diri untuk melakukan pendekatan ke komunitas mayarakat yang belum tentu mengerti kebutuhan masyarakat. Sementara, para 
bakal calon pilkada Sumatera Utara memiliki pekerjaan rumah yang penting untuk diselesaikan terkait dengan tidak berjalannya sistem dengan baik ketika 9 kali Kepala daerah yang tersandung kasus korupsi di Sumatera Utara (DiMedan.co, edisi April 2017). Pekerjaan rumah ini sedikitnya menyisakan rasa tidak percaya yang besar terhadap para bakal calon berikutnya. Jika masalah ini tak kunjung diselesaikan, bukan tidak mungkin masyarakat akan terus menyimpan hak suaranya, meningkatnya aksi curang atas surat suara yang kosong, dan akhirnya masyarakat lagi-lagi mau tidak mau harus apatis dengan tidak dilibatkan secara aktif dalam proses perumusan kebijakan dari awal, yaitu tidak memberikan suaranya ketika pilkada. Hal ini akan berpengaruh secara signifikan terhadap kebijakan publik yang dibuat sebagai luaran hasil kampanye para bakal calon yang terpilih karena banyak suara golput. Ironisnya, hal ini dilakukan berkali-kali sepengetahuan masyarakat yang membuat masyarakat Sumatera Utrara semakin enggan untuk terlibat dalam partisipasi politik secara aktif.

\section{Kekerasan Struktural (structural violence) dalam Politik}

Kekerasan struktural terjadi ketika seseorang atau golongan tertentu merasa dirugikan dalam bidang politik, hukum, ekonomi, atau tradisi budaya. Karena terjadi dalam waktu lama, kekerasan struktural pada umumnya terlihat biasa saja, sebuah fenomena yang selalu terjadi. Namun, kekerasan struktural menyebabkan penderitaan dan bahkan kematian seperti halnya kekerasan fisik, akan tetapi kerusakan yang disebabkan olehnya berakibat lebih lambat, lebih halus, lebih normal, dan lebih sulit untuk diperbaiki (Christie et.al, 2001).

Kekerasan struktural terjadi apabila tidak disadari; bentuk kekerasan non fisik tersebut dapat membatasi manusia lain untuk mengakses haknya. Kekerasan struktural juga bisa terjadi jika ketidaktahuan tersebut sudah mulai disadari dan tetap menjadi fenomena umum, sehingga lama kelamaan kekerasan penindasan hak atas manusia lain mengarah ke kekerasan banal Banal adalah suatu situasi, yaitu kejahatan tidak lagi dirasa sebagai kejahatan, tetapi sebagai sesuatu yang biasa-biasa saja, sesuatu yang wajar (Arendt et.al,1963).

Kekerasan struktural dalam politik dapat juga terjadi pada praktek kegiatan pemilihan kepala daerah (Pilkada). Dalam beberapa kasus kecenderungan masyarakat yang memilih tidak terlibat dalam kegiatan politik dikarenakan lingkungan dan perspektif individu yang tidak lagi melihat adanya peluang untuk menuju keadaan politik yang lebih 
baik. Struktur sosial dan iklim politik merupakan faktor dari luar yang mempengaruhi partisipasi politik masyarakat, jaringan interpersonal, dan bahkan institusi, sehingga membentuk opini politik dan membuat mereka menentukan keputusan politik (García,2009).

Dalam kajian ini membahas tentang kekerasan yang dialami oleh masyarakat Sumatera Utara dari tahun ke tahun, sehingga berakibat buruk pada implementasi sistem pemilihan kepala daerah. Masyarakat mau tidak mau harus mengalami berkali-kali kepemimpinan korup yang kemudian menjadi faktor utama penyebab maraknya apatisme masyarakat terhadap partisipasi politik. Masyarakat sudah lelah melihat berbagai paraktek politik yang dengan tujuan kampanye yang baik namun tidak terwujud dan berakhir dengan beberapa pemimpin yang masuk ke dalam lingkungan kriminal, membuat masyarakat semakin tidak percaya dengan segala tujuan politik ketika para bakal calon pemimpin daerah berkampanye. Sehingga, apatisme yang didukung tidak adanya kepercayaan masyarakat semakin meningkat dan menjadi kompleks dengan ditemukannya kasus para pemimpin terpilih melakukan tindak pidana.

Kekerasan struktural disebabkan kurangnya sosialisasi terhadap masyarakat tentang pentingnya keterlibatan mereka memilih pemimpin untuk jangka waktu lima tahun, merupakan salah satu faktor penting penurunan partisipasi politik masyarakat Medan dan peningkatan apatisme dalam Pilkada. Praktek kekerasan struktural ditunjukkan dari gejala penurunan partisipasi politik terjadi di tingkat pemilihan kepala daerah. Di sejumlah wilayah bahkan tingkat partisipasinya hanya di bawah 50\% (Pilgub Sumut 2013, Pilwako Medan 2010). Mayoritas masyarakat Indonesia ternyata merasa apatis terhadap masalah politik, dan trendnya memburuk. Apatisme politik ini sebanding dengan menurunnya tingkat partisipasi dalam setiap pemilu (Metro TV: Edisi 18 Juni 2013). Berita tersebut menjadi bukti bahwa masyarakat tidak ingin terlibat dalam menentukan nasib di daerahnya sendiri. Sikap apatisme masyarakat terhadap politik merupakan salah satu akibat fatal dari kegagalan sistem politik, dalam hal ini pemilihan kepala daerah, yaitu dalam hal ketidakikutsertaan masyarakat sebagai aktor penting dalam proses pembuatan kebijakan.

Perilaku politik dipengaruhi oleh sistem kultural yang melekat dan berlaku dalam masyarakat. Seperti yang disebutkan dalam pendekatan sosiologis mahzab Columbia, bahwa perilaku memilih ditentukan oleh status sosial ekonomi (SSE), agama, dan daerah tempat tinggal. Jadi, jikaseseorang berada di SSE tertentu, berarti ia memilih parpol 
tertentu. Jika ia beragama tertentu, ia akan memilih parpol tertentu, demikina juga jika ia tinggal di daerah tertentu, ia maka akan memilih parpol tertentu. Mazhab ini juga dikenal dengan nama pendekatan sosiologis atau sosial struktural (Lawrence, 2003; Redlawsk, 1997; \& Roth, 2008).

Dalam konteks analisa ini, penulis ingin mengidentifikasi bahwa perilaku politik apatis terhadap partisipasi politik, erat hubungannya dengan pendekatan yang dilakukan oleh bakal calon pemilihan kepala daerah. Contohnya, di wilayah Sumatera Utara, tingkat apatisme masyarakat pada partisipasi politik tidak bisa disebut sebagai fenomena biasa. Tingginya angka apatisme masyarakat terhadap partisipasi politik membuat kajian ini menarik yaitu mencapai 63,38\% (Detik.com edisi Selasa,12 Maret 2013).

Jika dianalisa, melalui kesukuan masyarakat Sumatera Utara adalah masyarakat majemuk dengan berbagai pendatang maupun suku asli Melayu, misalnya masyarakat keturunan Jawa, India, Melayu, Tionghoa, Batak dan masih banyak lagi , seperti yang tampak pada gambar di bawah ini.

Gambar 1: Perbandingan Etnis di Kota Medan Pada Tahun 1930,1980, dan 2000

\begin{tabular}{|c|c|c|c|}
\hline \multicolumn{4}{|c|}{$\begin{array}{l}\text { Perbandingan etnis di Kota Medan pada tahun 1930, 1980, dan } \\
2000\end{array}$} \\
\hline Etnis & Tahun 1930 & Tahun 1980 & Tahun 2000 \\
\hline Jawa & $24,89 \%$ & $29,41 \%$ & $33,03 \%$ \\
\hline Batak & $2,93 \%$ & $14,11 \%$ & $20,93 \%$ \\
\hline Tionqhoa & $35,63 \%$ & $12,80 \%$ & $10,65 \%$ \\
\hline Mandailing & $6,12 \%$ & $11,91 \%$ & $9,36 \%$ \\
\hline Minanqkabau & $7,29 \%$ & $10,93 \%$ & $8,6 \%$ \\
\hline Melayu & $7,06 \%$ & $8,57 \%$ & $6,59 \%$ \\
\hline Karo & $0,19 \%$ & $3,99 \%$ & $4,10 \%$ \\
\hline Aceh & - & $2,19 \%$ & $2,78 \%$ \\
\hline Sunda & $1,58 \%$ & $1,90 \%$ & $\cdots$ \\
\hline Lain-lain & $14,31 \%$ & $4,13 \%$ & $3,95 \%$ \\
\hline \multicolumn{4}{|c|}{ 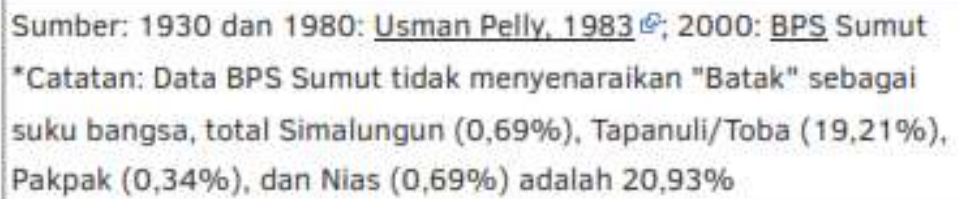 } \\
\hline
\end{tabular}


Tipe masyarakat yang majemuk ini membuat kebutuhan dan pengharapan mereka terhadap calon yang akan dipilih tentunya berbeda. Mereka yang datang dari berbagai latar belakang suku, agama, dan ras yang berbeda tidak cukup perwakilan yang mampu menyuarakan keinginan mereka di tingkat tinggi. Misalnya saja, kita ambil contoh dari suku yang paling banyak yaitu suku Jawa. Masyarakat asli suku Jawa dulunya didatangkan ke Sumatera Utara dengan alasan transmigrasi atas program pemerintah dan dijanjikan untuk mendapatkan lahan garapan berupa perkebunan ataupun menjadi pegawai perkebunan. Kemudian, dalam kancang politik mereka menginginkan porsi yang merata atas akases perkebunan maupun kepemilikan laha, klrena disitulah kepentingan hidup mereka. Namun, dengan alasan bukan suku asli dari Sumatera Utara, mereka tidak bisa membuat kebijakan untuk mengesahka hal tersebut. Sehingga, mereka perlu akses untuk masuk dalm perumusan kebijakan melalui pemasangan politik atau masuk sebagai anggota partai politik untuk dapat ikut merumuskan kebijakan yang akan membela kepentingan masyarakat Jwa di wilayah Suamtera Utara.

Mereka yang memiliki keterwakilan suara adalah mereka yang menang dalam konteks perebutan suara dalam pemilihan kepala daerah sebelumnya, memiliki koneksi di tingkat tinggi untuk mendulang suara, atau memiliki cara inovatif untuk menarik suara rakyat.

Kasus yang terjadi di Sumatera Utara, mengarah pada pilihan pertama dan kedua, yaitu menang dalam pemilihan kepala daerah sebelumnya atau memiliki koneksi di tingkat tinggi. Tidak dapat dihindari, bahwa bisnis dan politik adalah dua hal yang tidak bisa dipisahkan. Mereka pemangku kepentingan yang memegang kuasa atas roda bisnis di Sumatera Utara memiliki peluang lebih besar, begitu juga dengan mereka yang memiliki komunitas tertentu dengan keterwakilan suara di tingkat tinggi. Komunitas masyarakat berdasarkan kepentingan, ras, agama, atau suku tertentu bisa dijadikan identitas bahkan kendaraan politik yang efektif untuk mendulang suara. Akhirnya, sebagian besar masyarakat yang tidak terwakili memilih untuk menarik diri dan diam dalam proses pembuatan kebijakan sejak awal.

Faktor yang kedua adalah adanya keterbatasan akses untuk mendapatkan informasi tentang latar belakang, visi misi bakal calon, tidak aktifnya website KPU (laporan Bawaslu,Indeks Kerawanan Pilkada, 2015) dan masih banyak lagi keabsenan data yang seharusnya dengan mudah diperoleh masyarakat sebagai pemlih. Pada kasus pemilihan 
kepala daerah Sumatera Utara, masih banyak kendala yang dihadapi oleh Komisi Pemilihan Umum maupun Badan Pengawas Pemilu. Selain banyaknya daerah yang tidak terjangkau karena bencana alam atau memang terkendala akses infrastruktur, proses sosialisasi kepada masyarakat tentang bakal calon yang akan maju ke Pilkada hanya sebatas foto besar yang dipajang sebagai simbol kemunculannya di masyarakat. Pihak partai dalam hal kaderisasi juga kurang mekibatkan masyarakat untuk memberikan keterwakilan suaranya dalam pemilihan kepala daerah. Sehingga pekerjaan rumah yang belum terselesaikan harus terus ditumpuk menjadi sebuah agenda besar kampanye berikutnya.

Pendekatan sosial psikologis menyebutkan adanya tiga faktor yang berpengaruh terhadap perilaku memilih. Tiga faktor tersebut adalah identifikasi partai, orientasi isu atau tema dan orientasi kandidat. Identifikasi partai yang dimaksud di sini adalah bukan sekedar partai apa yang dipilih tetapi juga tingkat identifikasi individu terhadap partai tersebut misalnya, lemah hingga kuat. Lalu, yang dimaksud dengan orientasi isu atau tema adalah tema atau isu-isu apa saja yang diangkat oleh parpol tersebut. Sedangkan, yang dimaksud orientasi kandidat adalah siapa yang mewakili parpol tersebut. Menurut pendekatan sosial psikologis, tiga faktor itulah (identifikasi partai, orientasi tema dan orientasi kandidat) yang akan menentukan perilaku memilih (Lawrence, 2003; Redlawsk, 1997; \& Roth, 2008).

Jika dianalisa, penulis dapat menyimpulkan bahwa secara psikologis masyarakat Sumatera Utara tidak begitu dapat mengandalkan identifikasi partai, orientasi isu atau tema maupun orientasi kandidat. Misalnya dalam hal identifikasi partai, sebagian besar partai yang ikut dalam pemilihan kepala daerah memiliki kepentingan tertentu. Partai dinilai tidak dapat mendukung kepentigan rakyat apalagi kebutuhan rakyat. Oleh karena itu, isu atau tema kampanye yang diusung oleh bakal calon dari partai tidak akan lagi begitu menarik minat masyarakat (Tempo.co eidsi Kamis, 7 Maret 2013). Mengingat partai yang sudah lama ikut dalam pemilihan kepala daerah menciptakan rekor yang buruk dengan memilih bakal calon yang tidak banyak membawa perubahan positif, atau justru menjerumuskan dirinya dalam tindak pidana, misanya korupsi. Akhirnya, orientasi kandidat yang dibawa ketika kmampanye mendapat poin penilaian paling sedikit dari masyarakat. Pendekatan yang dilakukan oleh bakal calon atau partai yang mengikuti pilkada akhirnya hanya menjadi agenda perbaikan jalan, upaya menuntaskan masalah sampah, hingga upaya peningkatan pemerintahan yang bersih dari korupsi. Masyarakat 
dalam hal ini tidak membutuhkan janji yang terlalu tinggi, karena pada kenyataannya mereka sudah merasakan dampak dari keterwakilan yang buruk. Sehingga, yang banyak terjadi di lapangan adalah penerimaan masyarakat atas agenda partai konkrit, misalnya jalan sehat dengan pembagian hadiah, bersih-bersih sampah dengan imbalan kaos. Hal ini dikarenakan visi dan misi jangka panjang dari para bakal calon terpilih tidak lagi dapat diandalkan oleh masyarakat.

Pendekatan ketiga adalah pendekatan ekonomis biasa juga disebut dengan pendekatan rational-choice. Lalu, dari pilihan-pilihan tersebut, individu akan memilih pilihan yang memberi keuntungan paling besar bagi dirinya (Lawrence, 2003; Redlawsk, 1997; \& Roth, 2008). Berhubungan dengan pemilu, melalui pendekatan ini, pemilih diasumsikan mempertimbangkan segala pilihan yang ada, misalnya tiap-tiap parpol yang ada, tiap kandidat yang ada dan tiap-tiap kebijakan yang ada. Lalu, dilihat untung atau ruginya bagi individu. Pada akhirnya individu akan memilih yang memberi keuntungan paling besar dan kerugian paling kecil bagi dirinya.

Secara ekonomis, masyarakat Sumatera Utara memiliki masalah dengan kesenjangan sosial yang cukup tinggi. Jarak yang jelas terlihat ini memicu banyaknya tindak kejahatan, terutama di kota Medan (Harian Analisa, 22 Februari 2017). Kemiskinan merupakan penyebab banyaknya kemunduran di berbagai bidang, misalnya di bidang pendidikan, sosial, angka menikah muda yang tinggi, kesejahteraan masyarakat yang rendah, dan masih banyak lagi. Oleh karena itu, masyarakat yang ingin menentukan pilihan kepada bakal calon dalam pemilihan kepala daerah akan melihat kepentingan ekonomi sebagai sebuah pertimbangan yang tidak kalah penting. Pemerintah sendiri sudah berusaha mengarasi jarak ekonomi yang terjadi di masyarakat yaitu dengan meningkatkan eksploitasi di bidang pariwisata, perikanan, maupun menggratiskan pendidikan dasar hingga sekolah menengah pertama. Langkah ini diharapkan dapat meningkatkan kesejahteraan masyarakat. Namun, dengan banyaknya sumber daya manusia di wilayah Sumatera Utara dan kurangnya lapangan kerja yang tersedia, langkah-langkah pemerintah tersebut dinilai kurang efektif untuk meningkatkan kesejahteraan rakyat, bahkan atau meningkatkan taraf hidup rakyat di wailayah Sumatera Utara. Sehingga, masyarakat lagi-lagi merasa tidak butuh pemimpin yang menjanjikan banyak hal di masa kampanye, yang pada akhirnya mereka harus tetap berhadapan dengan kenyataan susahnya mencari penghidupan yang layak. 
Tingkat pendidikan juga berpengaruh dalam tingkat partisipasi politik. Faktanya, makin tinggi pendidikan masyarakat menjadi makin tinggi kesadaran politiknya. Demikian sebaliknya, makin rendah tingkat pendidikannya, makin rendah pula tingkat kesadaran politiknya (Novi A Malau, 2010).

Faktanya ditunjukkan dalam gambar di bawah ini:

Gambar 2: Diagram Ketertarikan terhadap Politik ditinjau dari Tingkat Pendidikan
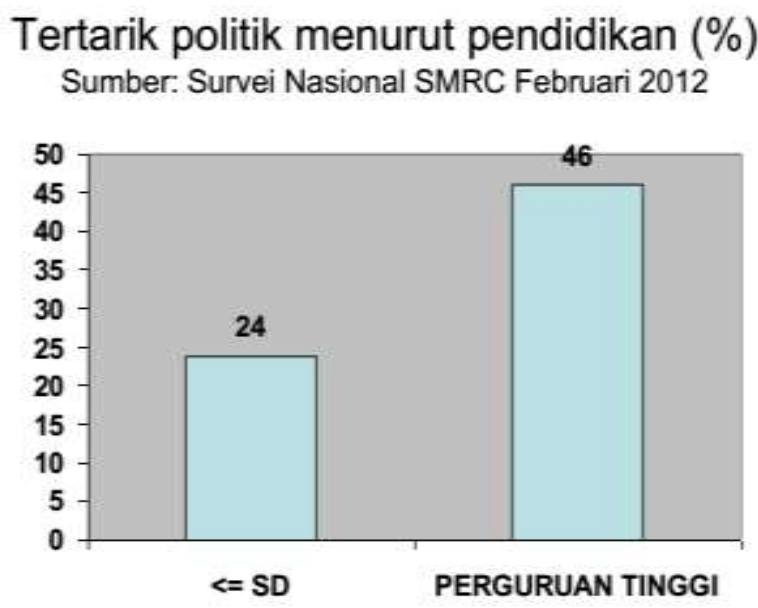

Yang kurang terpelajar lebih apatis.

\section{indikator}

Dalam gambar di atas bisa dilihat bahwa semakin tinggi tingkat pendidikan masyarakat, maka tingkat apatisme terhadap partisipasi politik semakin rendah. Kita juga bisa melihat fakta bahwa ketidaktahuan dalam bidang politik, yaitu pada mereka yang berpendidikan rata-rata SD memiliki sikap apatisme yang tinggi terhadap partisipasi politik. Hal ini disebabkan oleh praktek kekerasan struktural yaitu pembiaran atas ketidaktahuan tentang peran penting masyarakat dalam proses pengambilan kebijakan. Masyarakat dengan tingkat pendidikan rendah terbukti mengalami kekerasan struktural, mereka tidak mendapat haknya yaitu tidak mendapat sosialisasi politik yang sesuai. Hak suara mereka terbuang sia-sia dan menyebabkan hasil akhir Pilkada berada di tangan yang tidak seharusnya. Suara pemilih yang terbuang atau golput (Golongan Putih) kembali memperparah atmosfer politik di kota Medan karena perumusan kebijakan publik harus dibuat tanpa melibatkan masyarakat sebagai aktor maupun subjek pembangunan itu sendiri. 


\section{Apatisme dan Partisipasi Politik di wilayah Medan, Sumatera Utara}

Apatisme berasal dari bahasa Yunani, Apathy yang artinya bersikap acuh tak acuh. Dalam konteks politik, sikap ini merupakan hasil dari ketidakpercayaan masyarakat akan bakal calon yang akan dipilih dalam masa pemilihan kepala daerah. Sehingga, penurunan angka partisipan pemilih sangat tinggi dan merupakan kota tertinggi di tingkat Golput untuk pemilihan kepada daerah.

Kepercayaan terhadap institusi politik adalah orientasi evaluasi yang paling mendasar terhadap sistem politik. Seperti yang dikutip dari salah satu situs lembaga survey, Indikator Politik Indonesia Juni, 2013 yang menyebutkan bahwa kepercayaan terhadap institusi politik menentukan efektivitas pemerintahan dan legitimasi demokrasi (Easton, 1975; Hetherington, 1998). Secara teoretik, kombinasi antara kepercayaan pada institusi politik dan keterlibatan politik (political engagement) menghasilkan empat jenis warga negara (Seligson, 1980).

- Pertama, warganegara yang setia (allegiant), yakni mereka yang terlibat aktif secara politik, punya efikasi tinggi dan percaya terhadap institusi-institusi demokrasi.

- Kedua, warganegara yang teralienasi, yakni mereka yang memiliki efikasi politik, punya political interest tinggi, tapi institusi politik tidak sesuai yang mereka harapkan.

- Ketiga, warganegara yang naif, yakni mereka yang tidak aktif, tidak memiliki efikasi, tidak memiliki political interest, tapi percaya begitu saja terhadap institusi-institusi politik.

- Keempat, warganegara yang apatis, yakni mereka yang punya efikasi politik dan political interest yang rendah dan saat yang sama tidak percaya terhadap institusi politik.

Menurut data yang dirilis oleh beberapa lembaga survei tercatat angka partisipasi pemilih pada Pilkada serentak di 8 provinsi, 222 kabupaten, dan 34 kota. Dari data sementara, rata-rata partisipasi pemilih berkisar 50-65\%. Capaian ini jauh dari target KPU, yakni 77,5\%. Hal yang mengejutkan pada pelaksanaan Pilkada serentak di Sumatera Utara, bahwa partisipasi pemilih menurun drastis dari pelaksanaan demokrasi sebelumnya. Partisipasi pemilih di kota Medan, misalnya hanya sekitar 26\%. Dengan demikian, kota Medan menjadi daerah yang persentase partisipasi pemilihnya paling rendah di Indonesia 
atau daerah pemenang golput atau yang tidak berpartisipasi politik; dari 1,9 juta pemilih, sekitar 1,4 juta tidak memberikan hak suaranya (Andryan, 2015).

Menurut CEO Polmark Indonesia, Eep Saefullah Fatah, bahwa ada variabel dalam pelaksanaan Pilkada yang perlu dievaluasi seperti UU Nomor 8/2015 tentang Pilkada dan turunannya, yakni Peraturan KPU (PKPU) tentang Pilkada. Di sisi lain, ada faktor kejenuhan masyarakat di balik rendahnya tingkat partisipasi pemilih dalam Pilkada serentak (Andryan, 2015). Rendahnya partisipasi politik di daerah pada Pilkada serentak 2015, menimbulkan pandangan yang berbeda, ada yang menyalahkan penerapan sistem baru dalam proses demokrasi tersebut dan tidak sedikit pula yang menyalahkan kualitas sosok figur calon pemimpin di daerah, seperti diagram dibawah ini yang menjadi bukti rendahnya kepercayaan masyarakat terhadap insitusi politik.

Gambar 3: Trust terhadap Institusi Politik

\section{TRUST TERHADAP INSTITUSI POLITIK}
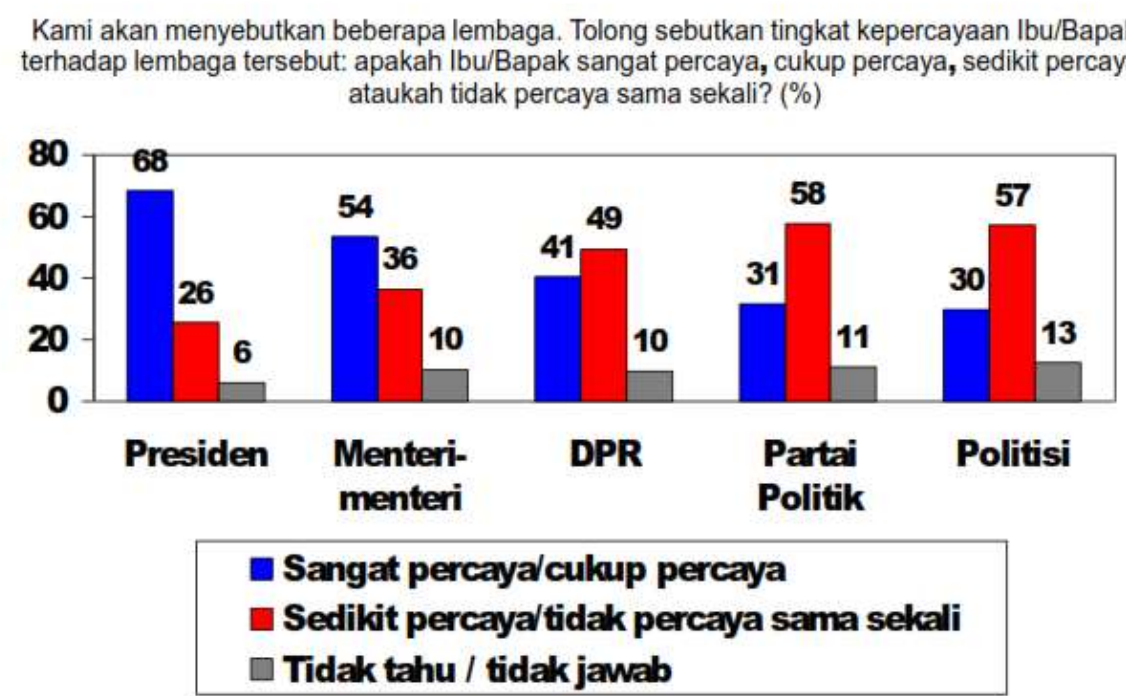

\section{indikator tollowys on @indikatorcoid}

Survei Nasional (Juni 2013)

Gambar di atas menunjukkan bahwa adanya ketidakpercayaan pubkik terhadap insititusi politik. Dalam konteks pemilihan kepala daerah Sumatera Utara, apatisme terhadap partisipasi politik didukung dengan adanya keterlibatan para kepala daerah Sumatera Utara yang terlibat dalam kasus korupsi, menimbulkan reaksi berupa apatisme masyarakat terhadap partispasi politik. Masyarakat merasa telah jenuh dengan sosok dan figur pemimpin yang terus menggunakan pencitraan, tanpa diikuti dengan perilaku baik 
serta merealisasikan janji-janji dalam segala bentuk kerja yang nyata. Misalnya, angka partisipasi pemilih di kota Medan hanya berkisar pada angka 26\%, menjadi catatan buruk dalam perjalanan politik. Hal ini tentunya membawa imbas akan kurangnya kepercayaan penuh terhadap pemimpin terpilih.

Sikap apatis disebutkan dalam buku Stephen R.Covey yang berjudul "The Speed of Trust: The One Thing that Changes Everything" atau Kecepatan Kepercayaan: Segalanya Bisa Merubah. Beberapa tanda krisis kepercayaan era kini adalah masyarakat kehilangan kepercayaan terhadap pemimpin. Tidak hanya itu, hilangnya kepercayaan antar pelaku pembangunan, membuat motivasi pembangunan melemah (Arsiman, 2017).

Gambar 4: Tipologi Pemilih berdasarkan data yang diperoleh dari hasil Survey Lembaga Indikator Politik Indonesia Juni, 2013.

\section{TIPOLOGI PEMILIH (\% TOTAL)}

\begin{tabular}{|l|l|c|c|}
\hline \multicolumn{2}{|c|}{} & \multicolumn{2}{c|}{$\begin{array}{c}\text { TRUST TERHADAP } \\
\text { INSTITUSI POLITIK }\end{array}$} \\
\cline { 3 - 4 } \multicolumn{2}{|c|}{} & TINGGI & RENDAH \\
\hline POLITICAL & TERTARIK & Setia & Teralienasi \\
INTEREST & & 17.0 & 13.2 \\
\cline { 2 - 4 } & TIDAK TERTARIK & Naif & Apatis \\
& & 28.3 & 41.5 \\
\hline
\end{tabular}

KETERANGAN:

- Trust terhadap institusi politik diperoleh dari indeks gabungan trust terhadap institusi politik. Indeks gabungan tersebut dihitung dari rata-rata trust setiap institusi politik (skala 1-4), kemudian skornya dibagi menjadi dua kategori (2.51-4.00=TINGGI, 1.00-2.50 =RENDAH).

- Political interest diperoleh dari jawaban seberapa tertarik responden dengan politik atau masalah pemerintahan yang dibagi dalam dua kategori (Sangat tertarik atau Cukup tertarik = TERTARIK, Kurang tertarik atau Sama sekali tidak tertarik = TIDAK TERTARIK)

- Nilai missing dikeluarkan dari analisis.

\section{indikator followus on @indikatorcoid}

Survei Nasional (Juni 2013)

Gambar di atas menunjukkan adanya angka apatisme yang tinggi yaitu 41,5\%. Akibat dari krisis kepercayaan terhadap pemipin wilayah Sumatera Utara berdampak luas terhadap pembangunan daerah. Wilayah Sumatera Utara yang memiliki pesona pariwisata strategis, didukung dengan posisi lintas perdagangan di ujung selat Malaka sangat disayangkan jika pembangunan merata yang sinergis dengan kemajuan kesejahteraan masyarakat tidak dapat dilaksanakan. Kepempinan di wilayah Sumatera Utara menciptakan iklim yang kurang kondusif untuk menyusun kebijakan publik yang efektif guna memajukan kesejahteraan masyarakat. 


\section{Sosialisasi dan Partisipasi Politik dalam Pemilihan Kepala Daerah}

Sosialisasi partai dalam Pilkada merupakan hal yang penting agar dapat mencapai tujuan, yaitu menyelenggarakan Pilkada yang aman, tertib, dan diikuti oleh seluruh masyarakat. Namun, 21 kecamatan dan 151 kelurahan yang ada di kota Medan, penyebaran informasi tentang Pilkada belum merata. Hal ini itu dikarenakan kesibukan masyarakat di ibukota Provinsi Sumut ini berbeda-beda. Tidak semuanya masyarakat kota Medan punya waktu membaca koran, mendengar radio atau mencari informasi soal Pilkada melalui gadget (alat elektronik) (Rio, 2015).

Komisi Pemilihan Umum dalam hal ini khususnya Kota Medan, merasa sudah melakukan tugasnya dengan baik, yaitu dengan penggunaan teknologi untuk melakukan sosialisasi tentang pemilihan kepala daerah melalui sarana gadget. Namun, dengan memperhatikan bahwa wilayah Sumatera Utara yang luas dan membentang dengan berbabai suku, budaya, dan agama, hal ini dinilai belum dapat menjadi sarana sosialisasi pemilihan kepala daerah yang efektif, terutama di wilayah pedesaan. Berikut ini adalah penjelasan dari KPU Medan, 2015:

"Kami sosialisasi udah maksimal kok. Dasar masyarakatnya saja yang apatis. Mereka tidak mau tahu," ujar Tamba. Memang mulai dari sejak masa kampanye kami sudah melihat masyarakat apatis. Ini ada sangkut pautnya dengan banyaknya pejabat yang tersangkut kasus korupsi. Makanya mereka berpikir buat apa memilih, toh, nanti korupsi".

Komisioner KPU kota Medan, Pandapotan Tamba, menampik penilaian bahwa tingginya tingkat golput pada Pilkada Medan karena kesalahan pihaknya. Tidak terima dengan penilaian yang mengatakan bahwa pihaknya kurang melakukan sosialisasi ke masyarakat. Meski demikian, Tamba tidak menampik bahwa golput memang tinggi. Menurutnya, masyarakat menjadi apatis karena bayang-bayang pejabat yang selalu berbuat korup sejak dilantik. Meski tingkat golput begitu tinggi, lanjut Tamba, hasil Pilkada ini tetap akan sah dan tidak akan ada pemilihan ulang (KPU Medan, 2015).

Berdasarkan penjelasan di atas bisa dilihat bagaimana kerja keras pihak KPU Medan yang masih kurang efektif untuk menarik minat masyarakat untuk ikut berpartisipasi dalam pilkada 2015. Dari pernyataan tersebut juga tersirat pengakuan dari pihak KPU terhadap tingginya angka ketidakpercayaan masyarakat terhadap para bakal calon yang akan maju dalam pilkada. Pesimisme dari pihak KPU ini juga menyiratkan 
bahwa dibutuhkan kerja keras dari partai politik peserta pemilu dan bakal calon di tingkat daerah untuk membangun kepercayaan publik dari masyarakat itu sendiri.

Partisipasi politik erat kaitannya dengan kepercayaan publik, tanpa itu mustahil masyarakat akan tergerak untuk ikut aktif dalam pemilihan baik pemilihan umum untuk presiden atau pemilihan kepala daerah. Masyarakat membutuhkan akses dan kepemimpinan yang transparan. Sayangnya, hal ini adalah sebuah agenda kampanye yang jarang bisa terealisasi. Dalam kasus korupnya kepemimpinan di wilayah Sumatera Utara, hal ini bisa diidentifikasi sebagai penyalahgunaan sumber daya dan power yang ada. Misalnya penyalahgunaan power melalui ormas atau komunitas di wilayah Sumatera Utara.

Tidak dapat dipungkiri, salah satu penggerak massa yang dominan di wilayah Sumatera Utara adalah organisasi masyarakat (ormas) dan komuniats kesukuan atau agama. Keduanya dirasa efektif untuk melakukan pendekatan yang signifikan di wilayah ini. Kultur masyarakat yang majemuk dan tidak mendapat jumlah keterwakilan yang seimbang di tingkat daerah membuat masyarakat lebih mempercayakan keamanan kepada ormas maupun komunitas tertentu. Sehingga, hal ini menjadi lahan penyalahgunaan wewenang dari para bakal calon untuk memanfaatkan ormas tertentu dengan imbalan uang atau kekuasaan jika terpilih.

Masyarakat dalam hal ini tidak dapat disalahkan, mereka telah mengalami kekerasan struktural sebagai akibat dari korupsi dan merasakan kurang meratanya pembangunan yang signifikan dilakukan oleh para kepala daerah yang berkuasa sebelumnya. Faktor tersebut didukung oleh adanya dukungan dari sektor bisnis. Para pelaku bisnis di wilayah Sumatera Utara, mulai melirik ke porsi kursi politik. Uang yang dimiliki digunakan untuk mendukung pasangan calon yang maju dalam persaingan pilkada, sebagai investasi. Bisa dibayangkan bahwa jika dengan modus seperti ini, kepemilikan kekuasaan di wilayah Sumatera Utara akan terus berputar di aliran uang investasi mereka, perwakilan yang didukung kuat oleh ormas maupun komunitas tertentu. Akibatnya, semakin jauh akses masyarakat terhadap para bakal calon yang akan dipilih, dan angka partisipan dalam pemilu semakin menurun yang disebabkan oleh tingginya tingkat apatisme terhadap partisipasi politik di wilayah Sumatera Utara. Faktor-faktor tersebut berpengaruh terhadap produk kebijakan publik di wilayah Sumatera Utara. 


\section{Korelasi Apatisme dengan Kebijakan Publik}

Kebijakan publik kemudian menjadi faktor terdampak dari adanya apatisme masyarakat dalam partisipasi politik. Definisi umum dari kebijakan publik adalah segala sesuatu yang diputuskan oleh pemerintah untuk dilakukan maupun yang tidak dilakukan (Anderson, 2003). Sesuai dengan definisi tersebut, pemerintah memegang peran penting dalam proses perumusan kebijakan publik. Kebijakan publik dapat dilakukan melalui dua cara, yaitu top down (dari atas ke bawah) dan bottom up (dari bawah ke atas). Setiap pengambilan keputusan dalam kebijakan publik seharusnya melibatkan unsur masyarakat. Oleh karena itu, peran masyarakat sangat penting, baik sebelum pembuatan kebijakan dilakukan maupun setelah proses pengambilan keputusan.

Proses dalam perumusan kebijakan publik ada beberapa versi. Salah satunya adalah versi Viana, 1996 berikut ini:

- Agenda setting

- Formulation

- Implementation

- Evaluation

Dalam proses perumusan kebijakan publik model Viana di atas, perumusan agenda disesuaikan dengan adanya masalah yang muncul. Kemudian, mulai dibentuk kebijakan melalui tahapan formulasi. Fase berikutnya adalah tahap penerapan kebijakan atau implementasi. Akhirnya, penerapan kebijakan di masyarakat akan dinilai melalui tahapan evaluasi, dalam tahapan ini merupakan penentuan efektifitas kebijakan itu sendiri.

Model perumusan kebijakan yang kedua menurut Brewer \& DeLeon, yang merupakan modifikasi dari model Viana:

- Agenda setting

- Estimation

- Selection

- Implementation

- Evaluation

- (Termination?)

Tahapan pertama dalam model perumusan kebijakan ini sama dengan model Viana, yaitu penetapan agenda yang disesuaikan dengan masalah yang ada. Kemudian, perkiraan atau estimasi, dalam tahapan ini dijelaskan beberapa alternatif (solusi) yang diberikan oleh para pakar yang berkompeten di bidangnya. Kemudian, proses seleksi dilakukan untuk 
menentukan solusi yang paling tepat dan efektif untuk dijadikan solusi dari permasalahan yang ada. Langkah berikutnya adalah penerapan kebijakan atau implementasi. Sama seperti model Viana, evaluasi dilakukan setelah kebijakan diterapkan di masyarakat. Tahapan terkahir sedikit berbeda dengan model Viana, yaitu adanya tahap terminasi atau penghentian kebijakan. Tahapan ini perlu dilakukan yaitu dengan menghentikan kebijakan yang dnilai tidak efektif untuk dijadikan solusi dari permasalah yang terjadi di masyarakat.

Kebijakan publik kemudian berujung pada kualitas pelayanan publik. Keduanya merupakan dua variabel penting dalam administrasi publik kontemporer yang memiliki hubungan kausalitas yang tinggi, tidak dapat dipisahkan walaupun bisa dibedakan fungsinya. Pelayanan yang baik harus bertitik tolak dari kebijakan publik sehingga memiliki dasar hukum yang jelas untuk mencegah terjadinya penyimpangan, agar tidak hanya sekedar ketentuan formal di atas kertas tanpa memberi makna terhadap kehidupan masyarakat (Budiman, 2013). Masyarakat dalam hal ini perlu diberi sosialisasi tentang pentingnya suara mereka dalam Pilkada yang nantinya menentukan proses perumusan kebijakan publik. Sehingga, pelayanan publik juga dapat dioptimalkan sesuai dengan kepentingan masyarakat.

Seperti yang telah dibahas sebelumnya, bahwa terdapat indikasi peningkatan apatisme masyarakat dalam partisipasi politik Pilkada Sumatera Utara yang berpengaruh terhadap kebijakan publik yang dibuat oleh kepala daerah terpilih sampai tahun 2015 .

Namun, sikap apatisme masyarakat terhadap partisipasi politik bahkan ketika sebelum kebijakan publik dibuat (sebelum pemilihan kepala daerah dilakukan) menjelaskan kurangnya efektifitas dalam proses pengambilan kebijakan, yaitu dalam proses agenda setting.

Kebijakan berhubungan erat dengan pelayanan publik yang mengikutsertakan masyarakat sebagai aktor (subjek) maupun objek di dalamnya. Kebijakan publik adalah produk politik, sehingga unsur unsur politik ikut mewarnai kebijakan yang dihasilkan.Sebagai produk politik, memang sarat dengan kepentingan politik golongan atau kelompok, namun proporsionalitas kepentingan dan harmoni menjadi sesuatu yang sangat penting diperhatikan untuk menghasilkan kebijakan yang baik.Masyarakat adalah pihak yang menjadi sasaran kebijakan (Budiman, 2013). Dengan kata lain, ketidakhadiran peran masyarakat dalam proses perumusan kebijakan merupakan salah satu indikasi tidak adanya keterwakilan suara atau kepentingan masyarakat. 
Absennya keterwakilan suara masyarakat melalui pemilihan kepala daerah, menimbulkan sebuah temuan yang dicurigai menjadi salah satu cara untuk mendulang suara. Hal ini dibuktikan dari adanya temuan bahwa 454.266 yang sudah berada di atas angka harapan hidup (AHH), seperti pernyataan Koordinator Divisi Pencegahan dan Hubungan Antarlembaga Bawaslu Sumut, Aulia Andri.

"Hasil analisis kita, ada sekitar 454.266 penduduk yang sudah berada di atas angka harapan hidup (AHH). Ini penting untuk diperiksa, apakah benar pemilih itu masih hidup. Jangan sampai nanti mereka masih masuk DPT dan suara mereka digunakan oleh pihak-pihak yang tidak bertanggung jawab,.... Pertama, dari potensi masih terdaftarnya penduduk yang sudah meninggal dunia dalam daftar pemilih. Analisis penduduk rentan telah meninggal dunia berdasarkan Proyeksi Penduduk Indonesia 2010-2035 yang dikeluarkan Badan Perencanaan Pembangunan Nasional (Bappenas) dan Badan Pusat Statistik (BPS) Tahun 2013,... Selama beberapa kali pemilu, kita mendapatkan bahwa orang yang sudah mati pun masih masuk daftar pemilih," kata Koordinator Divisi Pencegahan dan Hubungan Antarlembaga Bawaslu Sumut Aulia Andri Selasa (16/1/2018).

Masyarakat memiliki peran penting dalam pembuatan kebijakan publik hingga implementasinya. Jika apatisme masyarakat terhadap partisipasi politik tinggi, maka kemungkinan besar kebijakan publik yang nantinya diutamakan untuk kepentingan masyarakat juga akan beralih fungsi menjadi kepentingan golongan tertentu yang akan menunrunkan efektifiats kebijakan publik bagi pelayanan publik, terutama tingkat daerah.

Gejala penurunan efektifitas pembuatan kebijakan publik di kota Medan sekarang sudah bukan lagi hal yang tabu untuk dibahas. Dengan adanya fakta bahwa apatisme masyarakat Medan terhadap kegiatan politik di Pilkada menunjukkan bahwa mereka tidak tertarik untuk membuat perubahan bahkan terlibat dalam pengambilan keputusan di tingkat daerah.

Dalam artikel daring yang berjudul : Mengukur Kualitas Layanan Publik Pemko Medan di Harian Analisa edisi Senin, 27 April 2015, menyatakan bahwa Pemerintah Kota (Pemko) Medan mendapat predikat layanan publik terburuk secara nasional pada tahun 2011 berdasarkan penilaian Komisi Pemberantasan Korupsi (KPK). Adanya slogan di wilayah Sumatera Utara yang berbunyi "Kalau bisa dipersulit mengapa dipermudah", mendukung tingginya angka apatisme di wilayah Sumatera Utara, terutama mota Medan. "Slogan ini sangat kontra produktif bagi aparatur sipil negara. Sebab urusan jadi lamban dan bertele-tele. Bukan warga saja yang merasakan pelayanan publik Pemko Medan kurang baik. Tetapi juga dirasakan investor, soal ini Bank Dunia yang berkantor di 
Amerika Serikat itu mengatakan, orang harus mengurus 10 persyaratan sebelum memulai investasi di Indonesia. Akibatnya investasi ke daerah-daerah di negeri ini juga ke kota Medan kurang bergairah (Analisa, Senin, 27 April 2015.

Kurangnya investasi di bidang pembangunan yang diakibatkan oleh ribetnya birokarasi merupakan salah satu indikator kurang efektifnya produk kebijakan publik di tingkat wilayah. Selain itu, tingginya angka korupsi yang melibatkan beberapa kepala daerah Sumatera Utara membuat masyarakat semakin enggan melibatkan diri dalam partisipasi politik. Sehingga, menyebabkan kurangnya keterwakilan suara rakyat di tingkat daerah. Dengan kurangnya keterwakilan suara rakyat dalam pemilihan kepala daerah, sudah bisa diprediksi bahwa produk kebijakan publik yang dilahirkan dari absennya suara rakyat juga kurang efektif untuk meningkatkan kesejahteraan rakyat. Mereka yang terpilih justru lebih banyak menggunakan kesempatan untuk mengambil keuntungan pribadi.

\section{KESIMPULAN}

Penelitian ini menganalisa bagaimana angka partisipan dalam pemilihan kepala daerah berkorelasi secara signifikan terhadai efektifitas kebijakan publik. Di wilayah Sumatera Utara, khususnya kota Medan telah terbukti tingginya angka apatisme terhadap partisipasi politik merupakan sebuah hasil dari tingginya angka ketidakpercayaan publik terhadap institusi politik. Hal ini disebabkan adanya kemajemukan di tingkat masyarakat berpengaruh terhadap pengharapan keterwakilan suara di daerah. Namun, hal ini tidak pernah dicapai karena mereka yang menjadi wakil di tingkat daerah selalu menggunakan kekuatannya untuk menutup akses reformasi keterwakilan tersebut melalui komunitas ataupun ormas tertentu. Kepentingan golongan dan pribadi masih menjadi prioritas. Beberapa pendekatan yang dilakukan oleh bakal calon terpilih masih dinilai kurang untuk mendongkrak kepercayaan publik terhadap institusi politik, terutama partai politik. Oleh karena itu, kebijakan publik yang dibentuk dinilai kurang efektif untuk meningkatkan kesejahteraan masyarakat Sumatera Utara, terutama Medan. Selain itu, sosialisasi dan kaderisasi juga berpengaruh dalam upaya peningkatan jumlah partisipan pemilihan kepala daerah. 


\section{UCAPAN TERIMA KASIH}

Alhamdulillah, segala puji bagi Allah karena atas berkat dan rahmatnya penulis dapat menyelesaikan laporan kemajuan dari penelitian dosen pemula dengan judul "IDENTIFIKASI APATISME POLITIK BERKORELASI DENGAN KEBIJAKAN PUBLIK KOTA MEDAN". Penulis mengucapkan terima kasih yang sebesar-besarnya kepada semua pihak yang telah banyak telah membantu kelancaran penelitian ini, yaitu antara lain kepada : Pihak Kementrisn Riset, Teknologi, dan Pendidikan Tinggi Republik Indonesia (KEMENRISTEKDIKTI) yang telah mendanai penelitian ini. Tentu saja penelitian memiliki banyak kelemahan yang perlu disempurnakan untuk masa yang akan datang. Saran dan kritik bagi penulis sangatlah membantu dalam proses menyempurnakan maupun pengembangan bidang keilmuan. Akhir kata semoga penelitian ini dapat membantu dalam proses pengambangan bidang keilmuan untuk waktu yang akan datang.

\section{DAFTAR PUSTAKA}

\section{Buku:}

Anderson, J. E. Public policymaking: An introduction. Boston: Houghton Mifflin Company. 2003.

Christie, D. J., Wagner, R. V., \&Winter, D. A. (Eds.). (2001). Peace, ConflictandViolence: Peace Psychology for the 21st Century.EnglewoodCliffs, NewJersey: Prentice-Hall. 2007

Rusli, Budiman. Kebijakan Publik: Membangun Pelayanan Publik Yang Responsif. Bandung: Hakim Publishing. 2013

\section{Jurnal:}

Hemay, Idris dan Munandar, Aris. Jurnal Kajian Politik Dan Masalah Pembangunan JURNAL POLITIK VOL. 12 No. 01. 20161737 :Politik Identitas dan Pencitraan Kandidat Gubernur terhadap Perilaku Pemilih. Identity Politics and Imaging Governor Candidate to Conduct Voter. Bengkulu: Universitas Nasional. 2016.

Malau, Novi A. Jurnal Dinamika Politik Vol 1 no 2 Oktober 2012: Perilaku Etnis Batal Toba Dalam Pilkada Kota Medan. 2010.

Miguel García. PoliticalViolence And ElectoralDemocracy In ColombiaParticipation And Voting Behavior In ViolentContexts. University of Pittsburgh. 2009

Arendt, Hannah. Eichmannin Jerusalem. New York: Macmillan Company. 1963. 
Arsiman, https://jakarta.kemenkumham.go.id/download/karya-ilmiah/pelayanan-publik/72peran-kepemimpinan-dalam-membangun-kepercayaan-masyarakat-terhadappelayanan-publik/file.

\section{Artikel:}

Ammar. KPU Medan:Masyarakat Enggan Nyoblos Karena Pejabat Selalu Korupsi.2015. $\begin{array}{lllllr}\text { Diakses } & \text { Pada } & 27 & \text { Mei } & 2017 & \text { pukul }\end{array}$ WIB.http://medan.tribunnews.com/2015/12/09/kpu-medan-masyarakat-enggannyoblos-karena-pejabat-selalu-korupsi

Andryan.Golput dan Apatisme Politik Kota Medan.2015. Diakses Pada 27 Mei 2017 pukul 13.00 WIB. http://harian.analisadaily.com/opini/news/golput-dan-apatisme-politikdi-kota-medan/198199/2015/12/17

Ardani, Analisa. Mengukur Kualitas Layanan Publik Pemko Medan di Harian Analisa edisi Senin, 27 April 2015

Bawaslu, Indeks Kerawanan Pilkada 2015

http://ppid.bawaslu.go.id/sites/default/files/dokumen\%20berkala/Laporan\%20IKP\%20201 5.pdf

Indikator Politik Indonesia: Apatisme Politik. Bahan "Angka Bicara" Metro TV Edisi 18Juni 2013.

KabarMedan.com edisi 17 Desember 2015: Pikada Medan Pegang Angka Rekor Golput tertinggi 74Persen

Rio. Masyarakat Medan Apatis Sambut Pilkada.2015. Diakses Pada 27 Mei 2017 pukul 13.20 WIB.Akses Riaumandiri.co Via Mobile m.riaumandiri.co

Sagita Purnomo. Tingginya Kesenjangan Sosial di Sumut

http://harian.analisadaily.com/opini/news/tingginya-kesenjangan-sosial-disumut/323987/2017/02/22

Sinar Indonesia Baru edisi Desember 2015: Golput Menang Pilkada Kota Medan Ceritamedan.com edisi 20 September 2013.Mengenal Suku di Medan 